\title{
ULTIMUM REMEDIUM PRINCIPLES IN CRIMINAL DECISIONS IN CREATING RESTORATIVE JUSTICE
}

\author{
ASAS ULTIMUM REMEDIUM PADA PUTUSAN PIDANA ANAK \\ DALAM MENCIPTAKAN KEADILAN RESTORATIF JUSTICE*
}

\author{
Rina Melati Sitompul ${ }^{1}$, Andi Maysarah ${ }^{2}$ \\ Fakultas Hukum Universitas Dharmawangsa \\ Jl. Kol. Yos Sudarso No. 224 Glugur Kota, Kec. Medan Barat, Medan, Sumatera Utara \\ e-mail: nari.melati@gmail.com ${ }^{1}$ \\ e-mail: andimaysarah@dharmawangsa.ac.id ${ }^{2}$
}

\begin{abstract}
Principles are the heart of law, where their application becomes a form of awareness for judges in making decisions. The concept of this study analyzes the extent to which the ultimum remedium principle becomes the basic principle of judges to remove children from prison. Because the ultimate goal of achieving this principle is to encourage resolution of the problem by involving perpetrators, victims, and other parties in seeking a just solution by emphasizing recovery back to its original state. The form of this research is a normative juridical study with a descriptive analytical approach, which takes a sample of 7 (seven) verdicts in child criminal cases in 2 (two) jurisdictions, namely the Medan District Court and the Stabat District Court. In the conclusion of the results formulating the provisions of Law no. 11 of 2012 becomes a form of certainty to make it easier for judges to make the best decisions for children as the principle of ultimum remedium principle, although there are still some judges acting based on the theory of retaliation when concluding responsibility for children's mistakes.
\end{abstract}

Keywords : Principle of Ultimum Remedium; Child Criminal Justice; Restorative Justice.

\begin{abstract}
Abstrak
Asas merupakan jantungnya hukum, dimana penerapannya menjadi satu bentuk kesadaran bagi hakim dalam mengambil keputusan. Konsep kajian ini menganalisis sejauh mana Asas ultimum remedium menjadi prinsip dasar hakim untuk menjauhkan anak dari penjara. Karena tujuan akhir pencapaian prisip ini adalah terdorongnya penyelesaian masalah dengan melibatkan pelaku, korban, dan pihak lain dalam mencari penyelesaian yang adil dengan menekankan pemulihan kembali pada keadaan semula. Bentuk penelitian ini merupakan kajian yuridis normatif dengan pendekatan deskriptif analitis, yang mengambil sampel 7 (tujuh) putusan perkara pidana anak di 2 (dua) wilayah hukum yakni Pengadilan Negeri Medan dan Pengadilan Negeri Stabat. Kesimpulan hasil merumuskan ketentuan UU No. 11 Tahun 2012 menjadi satu bentuk kepastian untuk mempermudah hakim mengambil keputusan yang terbaik bagi anak sebagaimana prinsip Asas ultimum remedium, meskipun masih ada beberapa hakim dalam bertindak berlandaskan pada teori pembalasan saat menyimpulkan pertanggung jawaban atas kesalahan anak.
\end{abstract}

Kata Kunci: Asas Ultimum Remedium; Peradilan Pidana Anak; Restoratif Justice.

\footnotetext{
* Naskah diterima: 12 Januari 2021, direvisi: 11 September 2021, disetujui untuk terbit: 22 September 2021 Doi: $10.3376 /$ jch.v7i1.324
} 
Rina Melati Sitompul, Andi Maysarah: Asas Ultimum Remedium Pada Putusan Pidana...

\section{PENDAHULUAN}

Asas sama dengan prinsip yang merupakan sesuatu yang dapat dijadikan sebagai alas dan dasar, sebagai tumpuan dan tempat untuk menyandarkan, serta mengembalikan sesuatu hal, yang hendak dijelaskan. (Mahadi, 1991) Dalam pemahaman AR. Lacey dalam " $A$ Dictionary of Philosophyny" menjelaskan arti asas atau principle yakni: asas merupakan suatu hukum yang tinggi letaknya dan padanya dapat digantungkan, disandarkan disendikan banyak hukum-hukum lain. (Mahadi, 1991)

Nilai atau Asas hukum merupakan jantungnya peraturan hukum, sebagai landasan yang paling luas bagi lahirnya suatu peraturan hukum, yang menyimpulkan alasan mengapa hukum itu perlu dibuat atau ratio legis dari peraturan. Dengan kata lain asas hukum itu tidak akan pernah habis kekuatannya dengan melahirkan suatu peraturan hukum yang akan tetap ada untuk melahirkan aturan-aturan hukum lanjutan. (Satijipto, 2000)

Paton mengemukakan asas hukum merupakan sarana yang membuat hukum itu hidup, tumbuh dan berkembang, ia juga menunjukkan bahwa hukum itu bukan sekedar kumpulan dari peraturanperaturan belaka. Namun ia memiliki nilai-nilai dan tuntutan etis sebagai jembatan dalam penyambung cita-cita sosial dan pandangan etis masyarakat. (Satijipto, 2000)

Tatanan hukum mengenal adanya asas ultimum remedium sebagai salah satu asas dalam hukum pidana Indonesia yang menyatakan bahwa pemidanaan hendaklah merupakan satu upaya terakhir dalam penegakan hukum pidana. (Sudikno Mertokusumo, 2005) Sebagaimana tujuan pemidanaan digambarkan konsep Ultimum Remedium dimana penjatuhan sanksi pidana dapat diberikan kepada orang yang tepat karena pelaku tindak pidana juga memiliki peluang masa depan untuk memperbaiki diri. (Novita Sari, 2017)

Hal senada menyimpulkan Azas Ultimum Remedium merupakan azas dalam hukum pidana dimana pemidanaanya atau sanksi pidana adalah merupakan alternatif atau upaya terakhir bukan sebaliknya yakni bersifat ultimum premium yang penegakan pidana lebih mengedepankan sanksi pidana berupa pengenaan penderitaan terhadap seseorang. (Subyakto, 2015)

Konsep penanganan permasalahan anak yang berkonflik dengan hukum, dalam tatanan kebijakan politik hukum pidana mendapat sorotan penting dari waktu ke waktu. Berbagai upaya dilakukan agar keterlibatan aparat penegak hukum sebagai pengemban amanah untuk bisa bijak memberikan perhatian serius dalam penanganan penyelesaian kepada anak yang melakukan tindak kejahatan.

Disparitas layanan dalam pencapaian keadilan seperti yang dikemukakan Muhaiman dalam artikelnya dengan judul "Restotratif Justice Dalam Penyelesaian Tindak Pidana Ringan" dalam jurnal De Jure, No. 10 Tahun 2019, cukup gamblang mengurai konsep yang 
melatarbelakangi penelitiannya dalam pencapaian nilai keadilan, dimana geraknya cukup cepat dan lebih tajam jika menyangkut permasalahan orang kecil yang mempersoalkan kepentingan dengan orang yang berpengaruh atau orang penting. (Muhaimin, 2019) Tetapi jika menyangkut keterkaitan dengan pelakunya adalah orang-orang besar dan kekuasaan maka hukum seolah-olah lumpuh dan tumpul. Hukum tidak akan mampu menyentuh dengan alasan tidak cukup bukti atau tidak ada pelanggaran.

Sudikno Mertokusumo (Sudikno Mertokusumo, 2005) menitik tekankan hukum berfungsi sebagai perlindungan kepentingan manusia dalam penegakannya harus memperhatikan 3 (tiga) unsur fundamental hukum, antara lain: kepastian hukum (Rechtssicherheit), kemanfaatan (Zweckmassigkeit) dan keadilan (Gerechtigkeit). Oleh karena itu, dalam menentukan pemberian sanksi pidana dalam suatu undang-undang perlu memperhatikan ketiga unsur fundamental hukum tersebut karena pada dasarnya itulah yang menjadi hakikat dari tujuan hukum.

Salah satu hal alasan yang mendorong percepatan pembaharuan sistem peradilan pidana anak, dari konsep UU No. 3 Tahun 1997 tentang Pengadilan Anak kepada UU No. 11 Tahun 2012 tentang Sistem Peradilan Pidana Anak, karena pandangan kegagalan pencapaian pemidanaan tidak sesuai dengan harapan dan tujuan, sebagaimana alasan pemidanaan yang menjadi tujuan adalah: (PAF.Lamintang dan Theo Lamintang, 2012)
1. Untuk memperbaiki pribadi dari penjahat itu sendiri;

2. Untuk membuat orang menjadi jera dalam melakukan kejahatankejahatan;

3. Untuk membuat penjahat tertentu menjadi tidak mampu melakukan kejahatan yang lain, yakni penjahat yang dengan cara-cara yang lain sudah tidak dapat diperbaiki lagi.

Atas pandangan tersebut pemidanaan terhadap anak seyogianya menjadi alternatif terakhir sebagaimana pendekatan pidana dalam konsep SPPA harus berbeda dengan penanganan dalam UU Pengadilan Anak. (M. Nasir Djamil, 2013) Konsep pendekatan ini juga diamini bahwa konsep pemenjaraan adalah merupakan upaya terakhir, yang seyogianya mengedepankan pilihan secara pembinaan melalui jalur pendidikan guna masa depan anak. (Asliani Harahap, 2018)

Asas Ultimum Remedium adalah merupakan salah satu asas dalam hukum pidana yang menekankan proses penghukuman dengan pemidanaan adalah merupakan upaya terakhir dalam penegakan hukum. (Rahmi \& Lubis, 2017) Terhadap anak sebagai pelaku yang dihadapkan pada permasalahan hukum, pemenjaraan harus menjadi satu upaya terakahir.

Kejadian tindak pidana memang dapat mengganggu stabilitas keseimbangan dan keselarasan, namun pertanggung jawaban terhadap anak harus dibedakan sebagaimana tujuan pemidanaan adalah untuk memperbaiki kerusakan individu dan masyarakat yang 
Rina Melati Sitompul, Andi Maysarah: Asas Ultimum Remedium Pada Putusan Pidana...

diakibatkan oleh tindak pidana. (Susanti, 2019) Lebih lanjut memposisikan ketentuan penegakan hukum sebagaimana konteks asas legalitas ketentuan perbuatan apa yang dilarang harus bersesuaian dengan asas pertanggung jawaban. (Susanti, 2019)

Perlakuan layanan bagi anak yang berhadapan dengan hukum, menjadi satu pengkhususan sebagaimana anggapan bahwa masa depan anak masih cukup panjang. Maka seyogianya pertimbangan terbaik yang harus dikedepankan demi menjaga tumbuh kembang si anak. Sebagaimana lahirnya kebijakan sistem peradilan pidana anak menganut tatanan sistem politik hukum yang responsif yang dilihat dari pemulihan kedudukan korban dan pelaku kedalam bentuk semula sebagaimana pencapaian dalam wujud keadilan restoratif justice. (M. Nasir Djamil, 2013)

Sistem peradilan pidana anak sebagaimana telah diamanatkan oleh UU SPPA merupakan alternatif penyelesaian terbaik bagi Anak Berkonflik Hukum $(\mathrm{ABH})$ karena dalam penerapannya lebih mengutamakan prinsip kepentingan terbaik bagi anak baik dari segi fisik maupun psikologis anak dengan penerapan diversi. (Kristina Agustiani Sianturi, 2016)

Anak adalah generasi penerus bangsa yang memiliki keterbatasan dalam memahami dan melindungi diri dari berbagai pengaruh sistem yang ada. Masa anak-anak adalah masa yang sangat rawan melakukan tindakan, karena masa anakanak suatu masa yang sangat rentan dengan berbagai keinginan dan harapan untuk mencapai sesuatu ataupun melakukan sesuatu (Rahmi \& Lubis, 2017), oleh karena itu, pemeliharaan kelangsungan hidup anak adalah tanggung jawab orang tua yang tidak boleh diabaikan. (Rahmi \& Lubis, 2017)

Lebih lanjut dijelaskan kembali penjatuhan pidana penjara bagi anak akan menempatkan anak untuk tinggal dan melangsungkan kehidupannya di dalam penjara. Seperti yang diketahui bahwa masih kurangnya sarana maupun fasilitas di dalam penjara atau sekarang yang lebih sering disebut lembaga pemasyarakatan sangat memprihatin-kan. (Rahmi \& Lubis, 2017)

Hakim berfungsi dalam penyelesaian setiap perkara, yang disebut juga sebagai pelaksana inti secara fungsional menjalankan kekuasaan kehakiman. Dimana keberadaan hakim berperan penting dalam penegakan hukum dan pencapaian keadilan dalam putusanputusannya. (Bambang Sutiyoso, 2006). Putusan hakim merupakan satu mahkota atau puncak dari satu perkara yang sedang diperiksa. Oleh karenanya hakim dalam membuat putusannya harus memperhatikan segala aspek mulai dari kehati-hatian, penghindaran ketidak cermatan, dalam hal yang bersifat formal dan materil sampai kepada kecakapan tekhnik pembuatan.

Seorang hakim ketika membuat putusan saat menjatuhkan akan selalu berusaha agar putusannya dapat berterima di masyarakat, setidak-tidaknya berusaha agar lingkungan orang dapat menerima putusannya seluas mungkin. Hakim akan merasa lebih lega mana kala putusannya 
dapat memberikan kepuasan kepada semua pihak dengan pertimbanganpertimbangan yang sesuai dengan nilainilai kebenaran dan keadilan. (Ahmad Rifai, n.d.).

Mengukur sejauh mana putusanputusan hakim dalam menyelesaikan perkara pidana anak dalam konteks memberikan manfaat bagi semua pihak, sebagaimana upaya pencapaian keadilan restoratif justice, dilakukan penelitian putusan-putusan pidana anak di 2 (dua) Pengadilan Negeri yakni Medan dan Stabat, dengan satu konsep tolok ukur bagaimana pengaturan asas "ultimum remedium" dalam perundang-undangan di Indonesia yang terkait pada penyelesaian perkara anak yang berkonflik dengan dengan hukum, selanjutnya bagaimana penerapan asas "ultimum remedium" dalam menyelesaikan perkara pidana anak yang berkonflik dengan hukum dari 6 objek Putusan Pengadilan Negeri yang diteliti dan lebih lanut ingin mengetahui apa tujuan konteks keadilan Restoratif justice dari 6 Putusan Pengadilan Negeri itu tersebut.

\section{METODE PENELITIAN}

Metode yang dipergunakan dalam penelitian ini adalah metode deskriptif analitis dengan pendekatan yuridis normatif. Deskriptif analitis berarti menggambarkan dan melukiskan sesuatu yang menjadi obyek penelitian secara kritis melalui analisis yang bersifat kualitatif. Oleh karena yang ingin dikaji berada dalam ruang lingkup ilmu hukum, maka pendekatan normatif tersebut, meliputi: asas-asas hukum, sinkronisasi peraturan perundang-undangan, termasuk usaha penemuan hukum inconcreto. (Soerjono Soekanto and Sri Mamudji, 1985)

Di dalam suatu penelitian yuridis normatif, maka penggunaan pendekatan perundang-undangan (statute approach) adalah suatu hal yang pasti. Dikatakan pasti, karena secara logika hukum, penelitian hukum normatif didasarkan pada penelitian yang dilakukan terhadap bahan hukum yang ada. Meskipun misalnya penelitian dilakukan karena melihat adanya kekosongan hukum, namun kekosongan hukum tersebut dapat diketahui, karena sudah adanya normanorma hukum yang mensyaratkan pengaturan lebih lanjut dalam hukum positif. (Peter Mahmud Marzuki, 2006)

\section{HASIL DAN PEMBAHASAN}

\section{Pengaturan Asas "Ultimum Remedium" dalam Perundang- Undangan Di Indonesia Terkait Penyelesaian Perkara Anak Yang Berkonflik dengan Hukum}

Van Bemmelen berpendapat Utimum remedium diartikan sebagai upaya (middle), bukan merupakan alat untuk memulihkan ketidakadilan atau untuk memulihkan kerugian, melainkan upaya untuk memulihkan keadaan yang tidak tentram di dalam masyarakat, yang apabila tidak dilakukan sesuatu terhadap ketidakadilan itu dapat menyebabkan orang main hakim sendiri. (Zainal Abidin Fadir, 2010)

Sudikno Mertokusumo menjelaskan ultimum remedium merupakan istilah hukum yang biasa dipakai dan diartikan 
Rina Melati Sitompul, Andi Maysarah: Asas Ultimum Remedium Pada Putusan Pidana...

sebagai penerapan sanksi pidana yang merupakan sanksi pamungkas (terakhir) dalam penegakan hukum. (Rahmi \& Lubis, 2017) Sebagaimana dalam acuan kebijakan pidana pembentuk undangundang tidak memberikan penjelasan mengenai yang sebenarnya yang dimaksudkan dengan perkataan tindak pidana, maka akhirnya menimbulkan berbagai doktrin dan pendapat tentang maksud dari tindak pindana tersebut. (PAF Lamintang, 2011)

Pemahaman ultimum remedium sebagai obat terakhir, dipertegas Andi Hamzah yang menyatakan sedapat mungkin dibatasi, artinya kalau bagian lain dari hukum tidak cukup untuk menegakan norma-norma yang diakui oleh hukum, barulah hukum pidana diterapkan. (PAF Lamintang, 2011)

Pemidanaan adalah merupakan suatu nestapa kepada yang melakukan kesalahan tetapi tujuan akhirnya adalah berharap memperbaki atau memberikan kesadaran bagi pembuat kesalahan. Artinya jika seorang anak yang melakukan kesalahan dimasukan ke pendidikan paksa maksudnya adalah untuk memperbaiki tingkah lakunya yang buruk. (Andi Hamzah, n.d.)

Konsep pemidanaan menitik beratkan kepada Reformation, Restraint, Restribution dan Deterrence yang terdiri atas individual deterrence dan general deterrence (pencegahan khusus dan pencegahan umum). Reformasi maksudnya memperbaiki atau merehabilitasi penjahat menjadi baik dan berguna bagi masyarakat. Masyarakat akan memperoleh keuntungan dan tiada seorangpun yang merugi jika penjahat menjadi baik. Reformasi perlu digabung dengan tujuan yang lain seperti pencegahan dimana intensitas latihan di penjara lebih ditingkatkan.

Tujuan pemidanaan saat ini merupakan variasi dari bentuk penjeraan (deterrent) baik ditujukan kepada pelanggar hukum sendiri maupun kepada mereka yang yang mempunyai potensi penjahat. Perlindungan kepada masyarakat dari perbuatan jahat, perbaikan (reformasi) kepada penjahat yang cukup popular dimana bertujuan tidak saja kepada perbaikan pemenjaraan tetapi juga mencari alternative lain yang bukan bersifat pidana dalam membina pelanggaran.

Konvensi hak anak (KHA) yang telah diratifikasi melalui Keputusan Presiden No. 36 Tahun 1990 menjadi salah satu prinsip yang mendorong peradilan anak, dimana Negara wajib menjalankan tanggung jawabnya dalam perlindungan terhadap anak dalam bidang kehidupan agama, pendidikan, kesehatan dan sosial. Konsekuensi penandatangan Konvensi Hak Anak ini sebagai bentuk komitmen Negara untuk menjamin pemenuhan hak dasar anak. (Said, 2018) Sebagaimana dalam ketentuan Konvensi Hak Anak penangkapan, penahanan atau penghukuman anak hanya digunanakan sebagai langkah terakhir untuk masa depan anak.

Setelah diundangkannya UU No. 11 Tahun 2012 tentang Sistem peradilan Pidana Anak proses penyelesaian perkara anak lebih didahulukan di luar jalur pengadilan melalui Diversi dan Keadilan 
Restoratif. Tuntutan lebih mengutamakan keadilan atas perlindungan anak dari pada kepastian hukum, sehingga sangat memerlukan kesadaran penuh dari aparat penegak hukum untuk proses penyelesaian diluar jalur pemidanaan atau konsep ultimum remedium.
Pemenuhan konsep penanganan anak yang berkonflik dengan hukum dalam tatanan UU No.11 Tahun 2012 sebagai konsep ultimum remedium dirangkum dalam skema yakni :

\section{Skema 1 : Penanganan Anak Yang Berhadapan Dengan Hukum}

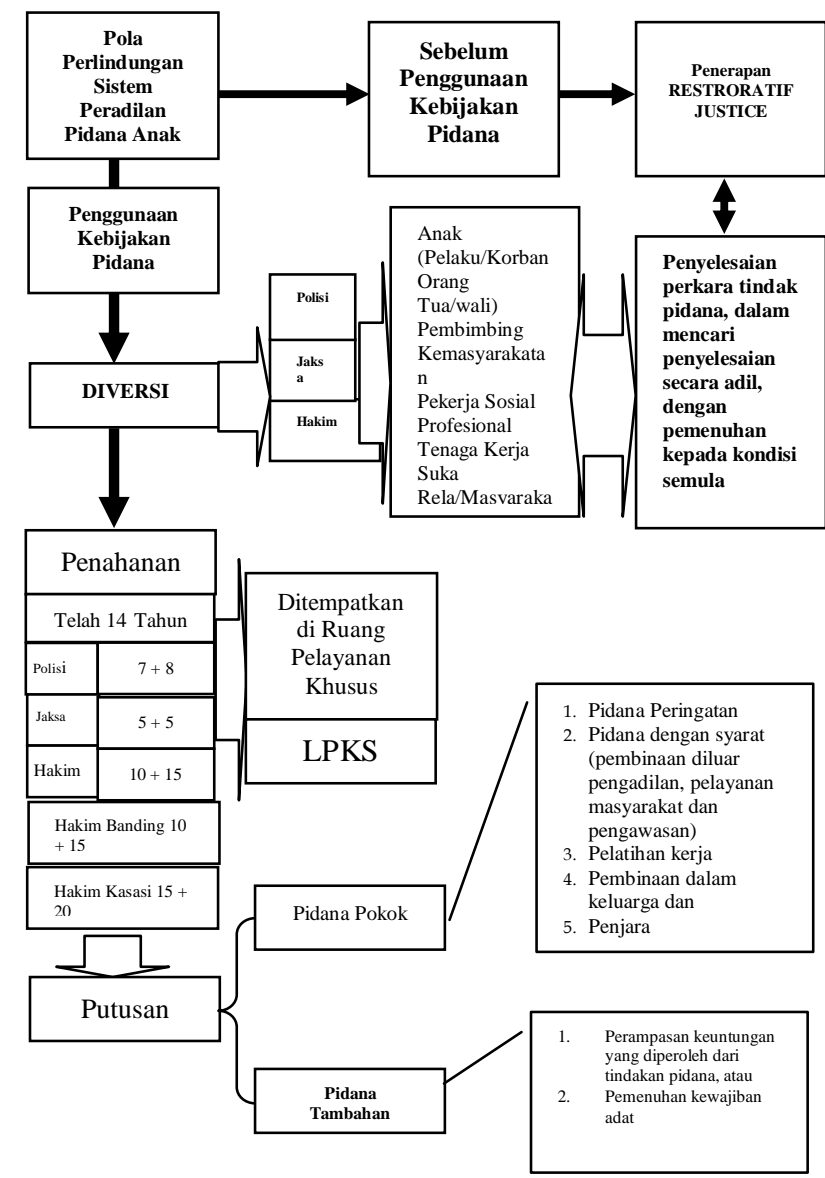

Alur penanganan skema diatas, menitik tekankan adanya kepastian sebagai mana dimaksudkan oleh Teori perlindungan sosial dan asas restorative justice, bagaimana hukum hadir di masyarakat untuk dapat diintegrasikan dan dikoordinasikan guna kepentingankepentingan melindungi anak. Terhadap hal-hal yang berbenturan satu dengan yang lain mampu diminimalisir semaksimal mungkin. (Satijipto, 2000)

Pengedepanan keadilan restoratife justice serta penerapan diversi dalam sistem peradilan pidana anak. Keadilan restoratife justice adalah penyelesaian perkara tindak pidana dengan melibatkan pelaku, korban, dan pihak lain yang terkait untuk bersama-sama mencari penyelesaian yang adil dengan 
Rina Melati Sitompul, Andi Maysarah: Asas Ultimum Remedium Pada Putusan Pidana...

menekankan pemulihan kembali pada keadaan semula, dan bukan pembalasan (Pasal 1 angka 6). Undang-Undang Sistem Peradilan Pidana Anak ini memberikan perlindungan terhadap hakhak anak yang dalam kategori juvenile delinquency karena adanya penerapan diversi, yaitu penyelesaian perkara diluar jalur pengadilan, namun hal ini dilakukan selama ancaman hukuman tindak kejahatan itu dibawah 7 tahun dan bukan merupakan tindak kejahatan yang sudah dilakukan berkali-kali oleh anak tersebut. (Dian Ety Mayasari, 2012)

Pembatasan terhadap penetapan penahanan terhadap anak, dimana sebagai pertimbangan yang cukup penting sebagai dasar dalam pemastian demi perlindungan terhadap anak, sebagai mana konsep dasar Lili Rasjidi dan Anthony M. Platt, yakni upaya penghindaran penjara terhadap anak dan pemenjaraan itu harus mampu memprediksi dan mengantisipasi sebagai bagian yang melindungi. Dalam kaitan pisau analisis tersebut, seyogianya ada hal yang menjadi pembatasan sebagai syarat yaitu: (Distia Aviandari, 2013)

1. Penahanan terhadap anak tidak boleh dilakukan dalam hal anak memperoleh jaminan dari orang tua/wali dan/atau lembaga anak tidak akan melarikan diri, tidak akan mengulangi tindak pidana.

2. Penahanan anak dapat dilakukan jika memenuhi beberapa persyaratan, yaitu anak telah berumur 14 tahun atau lebih, diduga melakukan tindak pidana dengan ancaman pidana penjara 7 (tujuh) tahun atau lebih.
3. Masa penahanan untuk tiap tahapan peradilan lebih singkat dibandingkan masa penahanan yang diatur dengan undang-undang sebelumnya.

Merujuk Pasal 6 UU No. 11 Tahun 2011 sebagai mana dalam konsep pendekatan melalui penerapan pidana. Terhadap konsep Diversi sebagai upaya proses perdamaian antara korban dan anak, dalam menyelesaikan perkara anak di luar proses peradilan, bertujuan penghindaran anak dari perampasan kemerdekaan, dan mendorong masyarakat untuk berpartisipasi dan menanamkan rasa tangung jawab kepada anak yang saat ini sudah mulai tergerus.

Otoritas dalam penerapan Diversi berada dalam tataran institusi penegak hukum, baik Polisi, Jaksa maupun Hakim. Untuk keterlibatan masyarakat dalam mewujudkan perdamaian antara "pihakpihak yang berkonflik" menjadi catatan tersendiri. Terhadap konsep pola penyelesaian di luar pengadilan ini, apakah konteks Diversi dan Restoratif Justice, pada masa lampau cukup akrab dalam wilayah lingkungan tradisi masyarakat Indonesia, sebagai praktik adat dan sosial yang konstruktif dalam menangani kasus-kasus yang ada dikomunitas tanpa selalu melibatkan lembaga peradilan formil. (Distia Aviandari, 2013) 


\section{Penerapan Asas "Ultimum Remedium" dalam penyelesaian perkara pidana anak yang berkonflik dengan hukum dari 6 Putusan Pengadilan Negeri}

Kemaksimalan penerapan asas ultimum remedium terhadap putusan hakim, untuk memudahkan pencapaiannya peneliti mengambil 6 (enam) sampel putusan hakim dari pengadilan Negeri Medan dan Pengadilan Negeri Stabat. Sejauh mana kebijakan Hakim dalam kemandiriannya menerapkan konsep penyelesaian perkara pidana anak dengan kepatuhan terhadap konteks asas ultimum remedium.

Alasan pengambilan tempat mengingat Pengadilan Negeri Stabat merupakan wilayah pilot project Mahkamah Agung Republik Indonesia dalam menjalankan konsep restoratif justice sebagaimana aturan kebijakan UU No. 12 Tahun 2012 tentang Sistem Peradilan Pidana Anak. Sedangkan Pengadilan Negeri Medan dikarenakan wilayah yang cukup pruralis dengan suku agama dan ras yang menetap di kota Medan.

Tabel 1

Putusan Perkara Anak

Pengadilan Negeri Medan dan Pengadilan Negeri Stabat

\begin{tabular}{|c|c|c|c|}
\hline No & Nomor Putusan & Pengadilan & Hasil Putusan \\
\hline 1. & $\begin{array}{l}\text { Putusan } \\
\text { No. }\end{array}$ & Medan & Anak di bebaskan dari Dakwaan \\
\hline 2. & $\begin{array}{l}\text { Putusan Nomor 1/Pid.Sus- } \\
\text { Anak/2020/PN Mdn }\end{array}$ & Medan & $\begin{array}{l}\text { Penjatuhan Sanksi Pidana } 1 \text { Tahun } \\
4 \text { Bulan terhadap Anak }\end{array}$ \\
\hline 3. & $\begin{array}{l}\text { Putusan Nomor } 4 \text { /Pid.Sus- } \\
\text { Anak/2019/PN Mdn }\end{array}$ & Medan & $\begin{array}{l}\text { Menjatuhkan pidana terhadap Anak } \\
\text { oleh karena itu dengan pidana } \\
\text { pelatihan kerja selama } 6 \text { (enam) } \\
\text { bulan di Rumah Inspirasi Training } \\
\text { Centre Yayasan Inspirasi Bangsa di } \\
\text { Jalan Komplek Pondok Surya Blok } \\
\text { I No. } 40 \text { Lk I Kelurahan Helvetia } \\
\text { Timur Kecamatan Medan dan } \\
\text { pidana pelatihan kerja selama } 3 \\
\text { (tiga) bulan di Dinas Sosial } \\
\text { Provinsi }\end{array}$ \\
\hline 4. & $\begin{array}{l}\text { Putusan Nomor 13/Pid.Sus- } \\
\text { Anak/2020/PN Mdn }\end{array}$ & Medan & $\begin{array}{l}\text { Pidana Penjara } 3 \text { Tahun kepada } \\
\text { anak }\end{array}$ \\
\hline 5. & $\begin{array}{l}\text { Putusan Nomor 13/Pid.Sus- } \\
\text { Anak/2020/PN Stb }\end{array}$ & Stabat & $\begin{array}{l}\text { Pidana } 10 \text { (sepuluh) bulan dan } \\
\text { pidana denda sebesar } \\
\text { Rp } 800.000 .000,00 \text { (delapan ratus } \\
\text { juta rupiah) dengan ketentuan jika } \\
\text { denda tersebut tidak dibayar maka } \\
\text { diganti dengan pelatihan kerja } \\
\text { selama 1 (satu) bulan }\end{array}$ \\
\hline 6. & $\begin{array}{l}\text { Putusan Nomor 13/Pid.Sus- } \\
\text { Anak/2020/PN Stb }\end{array}$ & Stabat & Pidana Penjara 10 (sepuluh) bulan \\
\hline
\end{tabular}


Rina Melati Sitompul, Andi Maysarah: Asas Ultimum Remedium Pada Putusan Pidana...

\begin{tabular}{lllll}
\hline 7. & Putusan Nomor & 5/Pid.Sus & Stabat & Pidana bersyarat dengan \\
Anak/2015/PN. Stb & & & pengawasan selama 6 (enam) bulan \\
& & dengan syarat Anak tidak boleh \\
& & melakukan tindak pidana selama \\
& & pengawasan \\
\hline
\end{tabular}

Sebelum sampai kepada potret putusan hakim, perbandingan data sebagai flash back yang dimiliki pihak BAPAS (Balai Pemasyarakatan) kota Medan sebagai lembaga yang selalu hadir dalam memberikan analisa sosial tentang status latar belakang dari anak kenapa sampai terjerumus masuk dalam permasalahan hukum.

Pentingnya informasi dari Bapas ini karena Bapas merupakan lembaga yang memiliki peran yang cukup penting dalam pemastian alteratif-alternatif pemberian tanggung jawab kepada anak sebagai pelaku. Dimana peran startegis Bapas ini dalam penyelesaian permasalahan anak berupa upaya permohonan penangguhan

Tabel 2.

Data Penanganan Terhadap ABH (Anak Konflik Hukum) Sebagai Pelaku

\begin{tabular}{llllll}
\hline No & Klasifikasi Putusan & 2018 & 2019 & 2020 & Jumlah \\
\hline 1 & Akord/Diversi & 33 & 12 & 19 & 64 \\
2 & Pidana Bersyarat & 5 & 2 & - & 7 \\
3 & Tindakan & 17 & 4 & 3 & 24 \\
4 & Pidana (LPKA) & 112 & 101 & 50 & 263 \\
\hline
\end{tabular}

*) Sumber BAPAS Kelas IA Medan, diakses pada tanggal 8 Nopember 2020

Hasil wawancara dengan pihak Bapas Medan, terhadap kepatuhan Hakim dalam proses penyelesaian terhadap permasalahan anak yang berkonflik dengan hukum perbandingan antara Hakim Pengadilan Negeri Medan dan Pengadilan Negeri Stabat, berbeda pandang dalam penerapan Asas Ultimum Remedium. Pertimbangan pengedepanan asas ultimum remedium sebagaimana penahanan maupun penyelesaian perkara dengan menggunakan prinsip-prinsip keadilan restoratif seperti diversi, dan dengan memberikan saran tindakan kepada hakim dalam persidangan anak yang berdasarkan pada rekomendasi dalam Penelitian Kemasyarakatan (Litmas) dari Bapas. (Anggara Dwi Putra, 2020)

Terangkum dalam Tebel Klasifikasi data anak yang masuk dari tahun-ke tahun sebagaimana data menunjukkan tingkat putusan pemenjaraan terhadap anak masih cukup tinggi. 
Beberapa putusan hakim sebagaimana yang tergambar dalam tabel ditemukan bentuk penjatuhan hukuman Hakim berupa :

1. Mengembalikan anak kepada orang tua untuk dibina dan diawasi.

2. Penempatan anak di Balai Latihan Kerja.

3. Putusan layanan sosial kepada masyarakat dengan melibatkan kepada desa, berupa membersihkan rumah Ibadah, membersihkan sarana umum yakni kantor kepala desa.

4. Pembebasan anak dari dakwaan Jaksa Penuntut Umum.

5. Pemenjaraan anak sebagaimana yang ditemukan dalam hasil putusan.

Sampel putusan hasil temuan terkonfirmasi antara Pengadilan Negeri Medan dan Pengadilan Negeri Stabat, konsistensi penerapan asas restoratif justice tergantung sepenuhnya dari kemauan dan pemahaman hakim yang menyidangkan berkas perkara anak. Dalam menerapkan Sistem Peradilan Pidana Anak Hakim-hakim di Pengadilan Stabat lebih konsisten memberikan hasil kesimpulan putusan yang mengarah kepada titik tekan pada pelatihan kerja. Sedangkan putusan di Pengadilan Negeri Medan lebih berpariasi, dimana masih terdapatnya penjatuhan hukuman penjara yang cukup tinggi yang diterima si anak. Namun disamping itu juga ditemukan juga putusan pidana anak yang sebagaimana dalam pertimbangan putusan telah memaksimalkan pencapaian restoriatif justice, yang mengedepankan kepentingan pemulihan kepada bentuk semula.

\section{Tujuan Konteks Keadilan Restoratif Justice yang Dituju dari 6 Putusan Pengadilan Negeri}

Proses pencapaian Teori Restoratif Justice, penyelesaian pelanggaran hukum tersebut dilakukan dengan membawa korban dan pelaku (tersangka) untuk bersama-sama berbicara. Dimana mediator akan memberikan kesempatan pada pihak pelaku untuk memberikan gambaran yang sejelas-jelasnya tentang tindakan yang telah dilakukannya, sehingga bisa mendapatkan perlakukan salah dari pelaku sendiri. Prosesnya semua pihak dilibatkan memecahkan masalah bagaimana menangani akibat di masa yang akan datang. (Hambali, 2019)

Hariman Satria dalam Jurnal Media Hukum mengemukakan, selain pencapaian keadilan restoratif justice, dalam proses menyelesaikan masalah anak juga diharapkan mampu mencapai keadilan masyarakat (community justice) yang dikemukakan oleh Todd R. Clear keadilan transisional (transit ional just ice) yang diprakarsai oleh Ruti G. Teitel dan keadilan transformatif (transformative just ice) dipelopori oleh M. Key Harris. (Satria, 2018)

Sebelum masuk dalam tahap proses pemberkasan semua tingkatan wajib terlebih dahulu melakukan proses diversi terlebih dahulu. Sehingga Hakim saat menerima berkas perkara anak, memiliki tanggung jawab untuk melihat kemungkinan berkas si anak apakah syaratnya dapat memenuhi proses upaya diversi guna mencari kata sepakat untuk 
Rina Melati Sitompul, Andi Maysarah: Asas Ultimum Remedium Pada Putusan Pidana...

tujuan terciptanya keadilan restoratif justice.

Ditilik dalam konsep pemahaman asas ultimum remedium, syarat diversi menjadi satu ketentuan yang pasti sehingga hakim yang memeriksa berkas pidana anak tidak ragu-ragu dalam memutuskan keputusan yang terbaik terhadap anak. Syarat diversi sebagaimana dalam Pasal 7 UU No. 1 Tahun 2012 yakni :

a. Diancam dengan pidana penjara di bawah 7 (tujuh) tahun.

b. Bukan merupakan pengulangan.

Satu hal menjadi konsep dalam mengukur bentuk kerugian yang diakibatkan anak, adalah kerugian yang diperbuat oleh anak tidak melebihi upah minimum dari tiap provinsi. Artinya nilai kerugian atas perkara yang dilakukan oleh si anak minimal Rp. 1.500.000,-. Hal yang perlu diperhatikan juga adalah dalam pencapaian proses kata sepakat antara pelaku anak dan korban potensi pemaksaan dan intimidasi diperkecil winwin solusi yang menjadi titik temu. Seorang anak tidak boleh merasa tertekan atau ditekan agar menyetujui programprogram diversi. Kesepakatan Diversi harus mendapatkan persetujuan korban dan/atau keluarga Anak Korban serta kesediaan Anak dan keluarganya.

Ancaman hukuman dibawah 7 (tujuh) tahun menjadi satu syarat penting yang wajib dijalankan, meskipun dalam konsep dakwaan yang disuguhkan oleh Jaksa penuntut umum mempergunakan dakwaan alterbatif atau subsideritas. Maka selama ada Pasal yang mendudukan ancaman dibawah 7 (tujuh) tahun penjara maka Hakim wajib terlebih dahulu melakukan upaya Diversi. Sebagaimana keterangan yang diperoleh dari salah seorang Bapas Kota Medan, salah satu Hakim di Pengadilan Negeri Medan, dikarenakan adanya peluang ancaman dibawah 7 (tujuh) tahun dalam subsider terendah, hakim melakukan Diversi kepada anak. Meskipun tidak berhasil, upaya untuk melakukan diversi wajib dilakukan.

Menilik dari ke-7 Putusan sebagai objek penelitian masing-masing keputusan yang diambil Hakim cukup pariatif. Pertanggung jawaban pidana badan sebagaimana yang dicerminkan dalam putusan Nomor 13/Pid.SusAnak/2020/PN Mdn dengan hukuman 3 Tahun penjara analisis putusan lebih mentikberatkan kepada unsur pembalasan agar si anak jera. Konsep pembalasan masih menjadi titik point yang cukup penting sebagaimana kewenangan hakim yang memutus. Disisi lainya terhadap putusan Bebas dalam perkara Nomor: 65/Pid.Sus-Anak/2015/ PN. Mdn kewenangan hakim berperan dalam melihat sisi keseimbangan antara keinginan masing-masing anak. Sebagaimana dakwaan yang cukup tinggi yang melibatkan pertanggung jawaban anak yang mengenyampingkan unsur sebab akibat. Sehingga ketika Hakim mengambil keputusan bebas mencoba menarik satu benang merah hakim mendudukkan putusan dengan keleluasaanya dengan konteks kemanfaatan UU No. 11 Tahun 2012, yang terbaik bagi anak. 
Putusan lainnya yakni Putusan Nomor 1/Pid.Sus-Anak/2020/PN Mdn, Putusan Nomor 4 /Pid.Sus-Anak/2019/PN Mdn, Putusan Nomor 13/Pid.SusAnak/2020/PN Stb, Putusan Nomor 13/Pid.Sus-Anak/2020/PN Stb, dan Putusan Nomor 5/Pid.Sus Anak/2015/PN. Stb mencerminkan proses penerapan asas ultimum remedium dalam mencapai keadilan restoratif justice.

Bukti penerapan konsep ultmum remedium dalam menciptakan keadilan restoratif justice, terangkum dalam salah satu pertimbangan putusan hakim yakni:

1. Bahwa berdasarkan rangkaian pertimbangan tersebut di atas, maka Hakim sependapat dengan tuntutan Penuntut Umum sepanjang analisis yuridis tuntutan Penuntut Umum terkait terbukti bersalahnya Anak melakukan tindak pidana yang didakwakan oleh Penuntut Umum

akan tetapi Hakim tidak sependapat dengan jenis dan lamanya pidana penjara yang diajukan oleh Penuntut Umum yang menuntut agar Anak menjalani pidana penjara selama 4 (empat ) tahun di dalam LPKA yang dipandang terlalu berat dengan alasan sebagai berikut:

2. Bahwa jenis pidana penjara terhadap Anak yang diajukan oleh Penuntut Umum di dalam tuntutannya tersebut dipandang telah mengabaikan martabat dan hak asasi Anak selaku seorang Anak yang berhadapan dengan hukum in casu berkonflik dengan hukum yang patut untuk mendapatkan perlindungan khusus karena sesuai dengan pertimbangan sebelumnya bahwa Anak telah diperalat oleh orang dewasa untuk terlibat dalam peredaran gelap narkotika, karena sesuai dengan asas yang dianut di dalam Sistem Peradilan Pidana Anak sesuai dengan Pasal 2 Undang-Undang Nomor 11 Tahun 2012 tentang Sistem Peradilan Pidana Anak pada huruf i bahwa perampasan kemerdekaan dan pemidanaan sebagai upaya terakhir.

\section{KESIMPULAN}

1. Pengaturan Asas "Ultimum Remedium" Dalam sistem Perundang-Undangan Di Indonesia Terkait Penyelesaian Perkara Anak Yang Berkonflik Dengan Hukum merupakan satu prinsip dasar untuk memastikan penyelesaian penanganan anak, penjara merupakan upaya terakhir. Untuk kepastian ruang gerak bagi aparat penegak hukum dalam pencapaian keadilan restoratif justice proses diversi menjadi satu jaminan yang harus dilalui sebelum memasuki tahapan pemeriksaan acara pidana untuk mencari penyelesaian secara adil untuk memulihkan kepada kondisi semula.

2. Penerapan asas "ultimum remedium" dalam penyelesaian perkara pidana anak yang berkonflik dengan hukum dari 7 (tujuh) Putusan Pengadilan Negeri tersimpulkan pemahaman prinsip hakim di masing-masing putusan masih memiliki perbedaan satu sama lainnya. Tidak semua hakim yang menangani perkara anak 
Rina Melati Sitompul, Andi Maysarah: Asas Ultimum Remedium Pada Putusan Pidana...

diatas mendasarkan putusan dengan prinsip Asas ultimum remedium, masih terdapatnya hakim dalam mengambil putusan berlandaskan kepada teori pembasalan dalam menyimpulkan kesalahan terhadap anak.

3. Tujuan keadilan Restoratif justice dari 7 Putusan Pengadilan Negeri, sebagai prinsip dasar dalam penerapan asas ultimum remedium. Hakim lebih dimudahkan dan leluasa merangkai pertimbangan ketika ingin menentukan putusan yang terbaik bagi anak, sebagaimana pertanggung jawaban kesalahan bagi anak yang melakukan kesalahan adalah lebih mendudukan kesadaran anak atas perbuatan yang dilakukannya dimana pemenjaraan bukan hal yang utama dalam memutuskan kesalahan dari anak.

\section{UCAPAN TERIMAKASI}

Pada kesempatan ini penulis memberikan penghargaan yang setinggitingginya kepada Yayasan Universitas Dharmawangsa yang telah memberikan kesempatan bagi para dosen di jajajaran Universitas Dharmwangsa untuk Anggaran tahun 2020, sehingga menjadi pemacu semangat dalam program wajib dari Lembaga Penelitian. Selanjutnya para nasumber dari BAPAS (Balai Permasyarakatan Kelas IA Medan) terimakasih atas konstribusi dan masukan sehingga penulis bisa maksimal mengurai konsep pencapaian dalam jurnal ini.

\section{DAFTAR PUSTAKA}

Ahmad Rifai. (n.d.). Penemuan Hukum oleh Hakim dalam persfektif hukum Progresif. Sinar Grafka.

Andi Hamzah. (n.d.). Asas-asas Hukum Pidana.

Anggara Dwi Putra. (2020). Restoratif Justice Sebagai Alternatif Penyelesaian Perkara Tindak Pidana Anak, Sesuai Dalam Undang - Undang Sistem Peradilan Pidana Anak. 4, 1-10.

Asliani Harahap. (2018). De lega lata. Hukum, 3(2), 204-216.

Bambang Sutiyoso: (2006). Metode Penemuan Hukum "upaya mewujudkan hukum yang pasti dan berkeadilan”,. UII Pers Yogyakarta.

Dian Ety Mayasari. (2012). Perlindungan Hak Anak Kategori Juvenile Delinquency. UNICEF Indonesia, Oktober(1), 109-128.

Distia Aviandari. (2013). Menuju Pemberlakuan UU No. 11 Tahun 2012 tentang Sistem Peradilan Pidana Anak. Pusaka Indonesia.

Hambali, A. R. (2019). Penerapan Diversi Terhadap Anak Yang Berhadapan dengan Hukum Dalam Sistem Peradilan Pidana ( Diversions for Children in Conflict with The Laws in The Criminal Justice System ). Jurnal Ilmu Hukum, 13, 15-30.

Kristina Agustiani Sianturi. (2016). Peradilan Pidana Anak Melalui Diversi. De Lega Lata, Volume I, Nomor 1, Januari - Juni 2016, I, 184-210.

M. Nasir Djamil. (2013). Anak Bukan Untuk Dihukum. 
Mahadi. (1991). Falsafah Hukum Suatu Pengantar. Bandung, Penerbit Alumni.

Muhaimin. (2019). De Jure De Jure. Jurnal Penelitian Hukum De Jure, 19(10), 517-538.

file:///C:/Users/Bimby/Downloads/4 00-2712-1-PB.pdf

Novita Sari. (2017). Penerapan Asas Ultimum Remedium Dalam Penegakan Hukum Tindak Pidana Penyalahgunaan Narkotika. 17(September), 351-363.

PAF.Lamintang dan Theo Lamintang. (2012). Hukum Penintensier Indonesia.

PAF Lamintang. (2011). Dasar-dasar Hukum Pidana Indonesia. Bandung: Citra Aditya.

Peter Mahmud Marzuki. (2006). Penelitian Hukum, kedua. Jakarta: Kencana Prenada Media Group,.

Rahmi, A., \& Lubis, S. P. (2017). Pertanggungjawaban Pidana Bagi Anak Yang Melakukan Kekerasan Fisik Terhadap Pembantu Rumah Tangga (Analisis Putusan Nomor: 27/Pid.Sus-Anak/2014/PN.MDN).

De Lega Lata, 2(2), 262-284. https://doi.org/10.31219/osf.io/cr3sy

Said, M. F. (2018). Perlindungan Hukum Terhadap Anak Dalam Perspektif Hak Asasi Manusia. JCH (Jurnal
Cendekia Hukum), 4(1), 141. https://doi.org/10.33760/jch.v4i1.97

Satijipto, R. (2000). Ilmu Hukum. In Ilmu Hukum.

Satria, H. (2018). Restorative Justice: Paradigma Baru Peradilan Pidana. 2(1), 111-123.

Soerjono Soekanto and Sri Mamudji. (1985). Penelitian Hukum Normatif. Jakarta: Rajawali.

Subyakto, K. (2015). Azas Ultimum Remedium Ataukah Azas Primum Remedium Yang Dianut Dalam Penegakan Hukum Pidana Pada Tindak Pidana Lingkungan Hidup Pada Uu Nomor 32 Tahun 2009 Tentang Perlindungan Dan Pengelolaan Lingkungan Hidup. Jurnal Pembaharuan Hukum, 2(2), 209-213.

Sudikno Mertokusumo. (2005). Mengenal Hukum Suatu Pengantar. Yogyakarta:Liberty,.

Susanti, D. E. (2019). Pemidanaan Terhadap Anak Sebagai Pelaku Tindak Pidana Studi Kasus Perkara Pidana No. 07/Pid-SusAnak/2017/Pn.Pdg. JCH (Jurnal Cendekia Hukum), 4(2), 187. https://doi.org/10.33760/jch.v4i2.10 3

Zainal Abidin Fadir. (2010). Hukum Pidana I. Jakarta: Sinar Grafika. 